\title{
The Comparison Study on Sharia Banking in Southeast Asian Countries
}

\author{
Eva Wany \\ Universitas Wijaya Kusuma Surabaya \\ Surabaya, Indonesia \\ Evawany.winarto@gmail.com
}

\author{
Maqbulla Arochman \\ Universitas Wijaya Kusuma Surabaya \\ Surabaya, Indonesia \\ Ula_aro@yahoo.co.id
}

\author{
Budi Prayitno \\ Universitas Wijaya Kusuma Surabaya \\ Surabaya, Indonesia \\ Joo_leo@yahoo.com
}

\begin{abstract}
Banking is a crucial element in the development of a country, This is reflected in the sense of Juridical Technique in Banking as a business entity that funds from the public in the form of deposits give to society in the form of credit and other forms of life improve in crowds, in the concept of Islam, commercial activities, services and trade must be adapted to the principles of Islam,. However Islamic banking is not just a bank "interest-free".. Based on Sharia banking market share issued by Bank Indonesia, Islamic banking in the country of Brunei Darusalam , Malasya and undergone rapid progress in comparison with Indonesia indicated with an increase in the assets of the Islamic banking in two of the country, as well as the Singapore population is muslim is as the minority showed significant progress in the Islamic banking industry, this research analyzes about banking banking conditions comparison began the process of management system , the growth and development of Islamic banking in Southeast Asian countries, the methods used in this research is qualitative method. The results obtained from this research is the growth of Islamic banking in Malasyajaug more rapidly compared with other countries in Southeast Asia.
\end{abstract}

Keywords - Islamic banking; comparison; growth

\section{INTRODUCTION}

In the concept of Islam, commercial activities, services, and trade must be aligned with Islamic principles such as "interest free". This explains the early stages of establishing an Islamic bank or sharia bank known as a "interest-free" bank. Nevertheless, sharia banking is not just a "interest-free" bank. This is because the "interest-free" view is a sharia bank developer trap that focuses only on the aspects of the transaction and diminishes its philosophical foundation (Umam, 2013: 16). Given the philosophy of sharia banking that based on the Qur'an and Sunnah, the development of Islamic banking is so easily accepted in the Muslim community and the Growhtso rapidly until now.
This is reflected in the era of the 1970s, efforts to establish sharia banks began to spread to many countries. Some countries such as Pakistan, Iran and Sudan, and even transformed the entire financial system in the country into a system non interest, so that all financial institutions in the country operate without using interest. In Islamic countries such as Malaysia and Indonesia, non interest banks operate side by side with conventional banks (Karim, 2004: 23).

Based on market share data of sharia banks issued by Indonesian Bangking, Syariah Banking in Malasya and Brunei Darussalam countries experienced rapid progress compared to Indonesia as shown by the increase of Islamic banking asset in both countries, as well as Singapore which the Muslim population as Minority showed sufficient progress significant in Sharia Banking Industry. Based on the background above, the researches feel interested to examine the Comparison of banking conditions began the process of system management, growth and development of sharia banking in Southeast Asian countries.

\section{LITERATURE REVIEW}

\section{A. Concepts of Sharia Banking}

The Islamization of science in the field of economics produces one of the products, namely pernamkansyariah (Islamic Bangking) which focuses on the elimination of interest as important in the Islamization of the economy. The term bank comes from the word Banque (french) or banco (italian language). In addition to eliminating usury, sharia banking as an institution that serves financial services also generates profits while maintaining the principles of Islamic business in accordance with the same rules of law as has been ordered to the Muslim person.

Overview of Islamic Banking and Finance in Southeast Asia Southeast Asia with a number of predominantly Muslim countries is of international concern in relation to the development of Islamic finance. The ability of the Islamic 
finance industry in the region to cope with the Asian currency crisis in the late 1990s and the recent global financial crisis at least acknowledged the importance of this region's position in this rapidly growing industry. The rapid and stable growth also makes Southeast Asia an important part of Islamic finance global.

\section{B. Sharia Finance in Southeast Asia Now and Its Challenges}

Southeast Asia will become the growth platform of sharia financial services. The demand for sharia financial products and services in the region is very significant. MuzaffarHisham, CEO of Maybank Islamic Bank Bhd, said the Southeast Asian region showed encouraging growth statistics with a population of over 600 million people and an average growth of 5.5 percent for 5 months of RRuto Domestic Product (GDP) for five years. "Southeast Asia as an industrial hub will generate significant demand for sharia financial products and services, especially from Indonesia, Malaysia and Singapore," he told a news conference at the World Islamic Economic Forum (WIEF), as quoted in The Malaysian Reserve recently .

Southeast Asia became one of the economic strengths in the Asian continent. Countries in the region are also developing sharia finance industry in every country, even with the level that different. The unification of Southeast Asian forces in the future will be conducted through the ASEAN Economic Community by 2015 . However, the President of the Union of Islamic Banking Institutions Malaysia, Dato 'MohdRedza Shah Abdul Wahid, said that the integration of the Islamic finance industry at the regional level is still somewhat difficult, except in terms of cooperation business and sharing of sharia financial information. According to him, the new integration process can be done in the expansion phase to ASEAN countries, such as those conducted by CIMB and HSBC. He says another difficult thing to realize integration is the difference pricing between one syariah financial institution in a country with another. Redza understands the condition because the supply and demand of each country is different. He acknowledged that the development of Islamic finance industry in Southeast Asia is not the same from one country to another. Indonesia and Malaysia are leading the way in the development of the nonribbon finance industry due to the presence of Islamic scholars and educational institutions that help.

\section{METHOD}

\section{A. Research Approach}

The research we conducted using qualitative research approach, where we do direct identification of elements revealed in sharia banking. Our qualitative research approach is chosen in the hope that we get real and accurate data and information so that the purpose of this research will be achieved. Object of research From what has been described in the previous chapter, the focus of this study is the Comparative Study of Sharia Banking Conditions in ASEAN Countries with State Samples being thoroughly Malasya,
Indonesia, Singapore and Brunei Darussalam. Of course, the object of this research is sharia entity, in this case is Banking Institution in Indonesia, Malasya, Singapore and Brunaidarussalam labeled 'Bank Syariah'. In Indonesia Data obtained from the Central Bank LibraryIndonesia Jakarta, Bank Indonesia Head Office Jakarta, OJK Office Jakarta, OJK Regional Office 4 Surabaya East Java, Bank Indonesia, Surabaya East Java, Data Center Negara NegaraMalasiya (BNM) and KMC (Knowledge Management Center) KualalumpurMalasiya

\section{B. Data Collection}

This research is preceded by preliminary survey at Bank Indonesia (BI) Surabaya East Java to get information of data that researchers need. We assume BI has a very wide information considering BI is the Policy Information Center and Banking System Governance in Indonesia, because the object of our research is sharia banking institutions. Bank Indonesia certainly has more detailed information from our research object.Next We Analyze Information on Sharia Banking Data in Malasya and Singapore on the Web then take care of Licensing for Collect Data to Bank Negara Malasiya and KMC (KnowledgeManagement Center ).

\section{DISCUSSION}

\section{A. Overview of Sharia Banking}

The Sharia Bank is an intermediary and financial services provider working on the basis of Islamic ethics and value systems, especially those free of interest, free from nonproductive speculative activities such as gambling, free from unclear and dubious matters ( gharar), based on justice principles, and only finance halal business activities. Sharia banks are often likened to banks with no interest. A noninterest-bearing bank is a narrower concept than a Sharia bank, when a number of instruments or operations are free of interest. Sharia Banks, in addition to avoiding interest, are also actively participating in achieving the goals and objectives of an Islamic economy oriented towards social welfare.

In the assessment of Global Islamic Financial Report (GFRI) in 2015 Indonesia ranks fourth country which has potential and conducive in the development of sharia financial industry after Iran, Malasya and Saudi Arabia. By looking at several aspects of the index calculation, such as the number of syariah banks, the number of non-syariah financial institutions, as well as the largest size of sharia financial assets, Indonesia is projected to be ranked first in the next few years. This optimism is in line with the high rate of institutional expansion and accelerated sharia banking asset growth coupled with the increasing volume of sukuk issuance.

Development of Islamic finance in Indonesia is more market driven and Bottom Up impulse in meeting the needs of society so that more relied on the real sector. Unlike the development of Islamic finance in Iran, Malasiya and Saudi Arabia, where the development of Islamic finance is more focused on the financial sector rather than the real sector and 
the role of government is very dominant in the development of Islamic financial industry, in addition to the form of regulatory support, placement of government funds and state- Islamic financial institutions make their total assets rise significantly, especially when those countries enjoy a windfall profit from rising oil and commodity prices.

The structure of the development of Islamic financial industry in Indonesia is another regulatory regime that is considered better than other countries. In Indonesia the authority to issue Islamic financial fatwa is centered by the National Sharia Council (DSN) - MajelisUlama Indonesia (MUI), which is an Independent Institution. While in other countries, fatwas can be issued by Individual Ulama so that the chances of difference are very large. In Malasiya, the organizational structure of this fatwa institution is carried by Bank Negara Malasya (BNM), does not stand independently.

Shariah governance model or system (shariah governance) Shariah financial institutions practiced in various countries vary. This difference occurs because of the different regulatory frameworks in each jurisdiction. This study analyzes the syari'ah governance framework of syari'ah banking in Indonesia, Malaysia, Singapore and Brunei Darussalam using a model developed by Hassan et al (2013) by dividing the aspects of shariah governance into 4 (four) main aspects, namely the regulation, organizational structure, process and function of the supervisory board of shari'ah.

Implementation of Islamic banking system in Malaysia has been proven to evolve through several approaches that encompass the dual banking system, the scope, the comprehensive law, the support of the capital market sector and the securities and supervision of banking and human resources. This integrated approach enables the implementation of Islamic banking system to run smoothly and expanding rapidly not only in Malasiya State but also outside Malasiya. From the aspect of managing the implementation of Islamic banking system also, generally we can see the positive development of the development of Islamic banking assets as well as the increase of banking products based on various concepts received by the public at home and abroad.

\section{B. Development of Sharia Banking in Singapore}

Islamic Bank of Asia (IBA) is listed as the first syariah bank in Singapore. The bank was approved by the Monetary Authority of Singapore in 2007. DBS, Singapore's largest local bank, became the majority shareholder of IBA, while the rest came from 22 Gulf Cooperation Council investors. The fast-growing sharia financial market has prompted a number of countries in Asia to offer sharia banking to raise Middle Eastern market investments. While the majority of Singaporeans are non-Muslim, it does not dampen DBS and Singapore's government for establishing sharia banks. The Muslim market in Singapore is small, about 14 percent of the total population of 4.5 million people. IBA, which initially focuses on the commercial sector, corporate finance, and capital markets, has shifted its attention to retail, particularly in the retail market in Malaysia and Indonesia. Asia is a top priority for IBA in expansion, although it also sees opportunities for expansion in Saudi Arabia, United Arab Emirates and Kuwait. Islamic banks turned their attention to retail consumers after the sukuk market suffered a slowdown due to the global economic crisis. The increasing demand for ethical investment and non-Muslim interest in sharia finance makes retail business a potential market.China Executive Cefe, Vince Cook said the Singapore-based bank is considering options for entry into Malaysia and Indonesia markets, including buying bank stocks banks in these countries. "Singapore has a great platform in cross-border business. Indonesia and Malaysia can equip it by giving us the opportunity to build a retail business there, "Cook said. Initially the bank had a paid up capital of 418 million US dollars, in which DBS injects funds of 250 million US dollars or equivalent to 60 percent share. But now IBA has a capital of 500 million US dollars. DBS also said it would hold shares at least half of the total shares in the future. In January, IBA won the trust to be the lead arranger for the first sukuk issuance in Singapore. Issuance of sukuk worth 200 million Singapore dollars issued by the Monetary Authority of Singapore.

\section{The Development of Syariah Bank in Brunei Darussalam}

Based on reports from the Brunei Darussalam AutoritiMonetari (AMBD), sharia banking experienced significant growth in 2010 with total assets reaching approximately B \$ 6.36 billion and total deposits of B \$ 5.167 billion, or $37 \%$ and $34.6 \%$ of total market share. This significant development has prompted the Brunei government to develop other Islamic financial sectors, such as takaful, sukuk and syariah capital markets. The Syariah financial industry in Brunei Darussalam is governed under the authority of "AutoritiMonetari Brunei Darussalam (AMBD)" or the Monetary Authority of Brunei Darussalam. AMBD was established and inaugurated in 2011 through the AutoritiMonetari Brunei Darussalam Order 2010 regulation. Prior to the establishment of AMBD as the central bank authority, the banking industry was under the supervision of the finance ministry (Finance Ministery).

\section{CONCLUSION}

As a result, Currently Malaysia's sharia banking assets have reached more than US $\$ 11.9$ billion or equivalent to Rp119 trillion (ISEO: 2011), and put Malaysia in the position of the top three global sharia finance industries. Currently, the assets of sharia banks in Indonesia are still inferior to conventional banks. "Syariah assets in Malaysia are 26\%, we are only $5 \%$.As the ideals to create sharia banking assets above $5 \%$ is still a challenge. Malaysia, need the help of all Parties of Government and Society to be able to develop financing and sharia economy in order to run together both conventional and sharia, Excess liquidity of sharia banks is also still minimal compared to conventional. BI noted that 
conventional banks placed an excess of Rp 270 trillion while sharia banks only Rp 16 trillion. The limitations of existing instruments in Indonesia have caused sharia banks to excess liquidity abroad such as Malaysia which has many syariah instruments. "So it can be imagined $270: 16$ The cake is still small.

Although in terms of asset capitalization and the start of sharia financial industry in Indonesia lags about 10 years from Malaysia, this does not mean that the future of sharia banking and finance in Indonesia is not as bright as other countries. The proof, the assets of Islamic banking in Indonesia in mid2010 has grown to touch the number Rp78.14 trillion. Yet according to records in 2000, the assets of sharia banking in the country only amounted to Rp1.79 trillion (ISEO: 2011).

The Muslim market in Singapore is small, about 14 percent of the total population of 4.5 million people. IBA, which initially focuses on the commercial sector, corporate finance, and capital markets, has shifted its attention to retail, particularly in the retail market in Malaysia and Indonesia.

Based on reports from the Brunei Darussalam AutoritiMonetari (AMBD), sharia banking experienced significant growth in 2010 with total assets reaching approximately B \$ 6.36 billion and total deposits of B \$ 5.167 billion, or $37 \%$ and $34.6 \%$ of total market share.

\section{REFERENCES}

[1] A. R. Amen. Organizing Islamic Banking in Indonesia, Jakarta: UIN Press, 2009.

[2] A. Reza, UIN Jakarta 2010 "Comparison of Syariah Banking in Indonesia and Islamic Republic of Iran.
[3] F. Amanda. Icha's personal blog, "History of National and International Sharia Banking". From http: // farisah amanda.blogspot.com/2010/03/sejarah-perbankan-syariahnasional.html. October 23, 2014.

[4] A. Yuli. Munich Personal RePEc Archive. "Book Review Current Issues in Islamic Banking and Finance in South East Asia". Fromhttp://mpra.ub.unimuenchen.de/58600/1/MPRA_paper_58600.pdf.22 Oktober 2014.

[5] National Sharia Council, Association of Fatwa National Sharia Council MUI, (DSN-MUI Jakarta, 2006), h.425

[6] [13] WashfieSaal, UIN Jakarta 2009.’'Islamic Banking in South Africa, Problems and Solution".

[7] M.D. Putri, UIN Jakarta 2008. "The Role of Sharia Banking in Creating Monetary Stability in Sudan".

[8] I. Rifki. Islamic Finance in the UK: Stadium General Islamic Economics. Presented at UIN SyarifHidayatullah, April 20, 2011.Directorate of Islamic Banking BI.

[9] P.A. Bagya. 2009. The Practice of Murobahah Scheme in Syariah Banking: Critical Analysis Towards the Application of Murobahah Scheme in Indonesia and Malaysia.

[10] Y. Andriansyah, Munich Personal RePEc Archive, Book Review Current Issues in Islamic Banking and Finance in South East Asia, http://mpra.ub.unimuenchen.de/58600/1/MPRA paper 58600.pdf, 22 Oktober 2014

[11] Officer, Daughter."Dynamics of Islam in Asia".Fromhttp: //putrinyaperwirafisip09.web.unair.ac.id/artikeldetail64067Com munity $\% 20$ Bulture $\% 20$ dan $\% 20$ Politik\%20Asia\%20TenggaraD inamika\%20Islam\%20di\%20Asia\%2TTenggara.html. October 24, 2014.

[12] Brunei Darussalam, http://en.wikipedia.org/ wiki/Brunei Darussalam, October 23, 2014. 